\title{
The effect and mechanism of bufalin on regulating hepatocellular carcinoma cell invasion and metastasis via Wnt/ $\beta$-catenin signaling pathway
}

\author{
JI QIN GAI ${ }^{1}$, XIA SHENG $^{2}$, JIAN MIN QIN $^{1}$, KANG SUN $^{1}$, WEI ZHAO ${ }^{1}$ and LEI NI ${ }^{1}$ \\ Departments of ${ }^{1}$ General Surgery, and ${ }^{2}$ Pathology, Putuo Hospital, \\ Shanghai University of Traditional Chinese Medicine, Shanghai 200062, P.R. China
}

Received August 28, 2015; Accepted October 11, 2015

DOI: 10.3892/ijo.2015.3250

\begin{abstract}
Hepatocellular carcinoma (HCC) is a highly malignant tumor with an extremely poor prognosis. Our preliminary study indicated that bufalin could restrain the proliferation of human hepatoma BEL-7402 cells in a time- and dosedependent manner. In the present study, the colony formation assay, the Transwell invasion assay, the western blot analysis and the immunofluorescence method were respectively used to investigate the effect and mechanism of bufalin against HCC cell invasion and metastasis. We found that: i) bufalin had significant inhibitory effect on the cell proliferation of BEL-7402 cells; ii) bufalin markedly inhibited the migration and invasion of BEL-7402 cells; iii) bufalin could suppress the phosphorylation of GSK-3 $\beta$ Ser9 site in BEL-7402 cells, decrease the expression of $\beta$-catenin, cyclin D1, metalloproteinases-7 (MMP-7) and cyclooxygenase-2 (COX-2) in the cytoplasm, and increase the expression of E-cadherin and $\beta$-catenin on the cell membrane; and iv) the expression of $\alpha$-fetoprotein significantly decreased and the expression of albumin increased in BEL-7402 cells after bufalin was used. Our results indicate that: i) bufalin can regulate the expression of associated factors in Wnt/ $/$-catenin signaling pathway of BEL-7402 cells through suppressing the phosphorylation of GSK-3 $\beta$ Ser9 site; ii) bufalin can strengthen intercellular E-cadherin/ $\beta$-catenin complex to control epithelial-mesenchymal transition; and iii) bufalin can reverse the malignant phenotype and promote the differentiation and maturation by regulating the AFP and ALB expression in BEL-7402 cells. These are very important mechanisms of bufalin on the inhibition of the invasion and metastasis of HCC cells.
\end{abstract}

Correspondence to: Professor Jian Min Qin, Department of General Surgery, Putuo Hospital, Shanghai University of Traditional Chinese Medicine, 164 Lanxi Road, Shanghai 200065, P.R. China E-mail: jianminqin@yahoo.com

Key words: bufalin, hepatocellular carcinoma, invasion, metastasis, $\mathrm{Wnt} / \beta$-catenin signaling pathway

\section{Introduction}

Hepatocellular carcinoma (HCC) accounts for $90-95 \%$ of all kinds of liver cancers, with nearly 500,000 new patients each year. It is a common malignant tumor in the digestive system, and the incidence is ranked the sixth of all cancers in the world. Patients with HCC are often diagnosed in the late stages due to the undetectable onset, so the overall prognosis is poor, making it the third ranked based on mortality in the world (1-4). Partial hepatectomy is currently preferred to treat HCC. However, only less than $30 \%$ of patients with HCC can finally be operated, because $60-90 \%$ of the patients have viral hepatitis and liver cirrhosis. Furthermore, the recurrence rate is $80 \%$ after operation at five years, it seriously affects the surgical curative effect $(1,5,6)$. Although liver transplantation can cure liver cancer without considering the cirrhosis condition and improve the total 5 -year survival rate to $70-80 \%$, it is restricted to be carried out widely because of high technical requirements, the shortage of graft source for transplantation, and the risk of health damage to donors during living donor liver transplantation and other disadvantages $(5,7)$. In order to get good therapeutic effects, all criteria of liver transplantation have limitations on the number and size of the tumors, the vascular invasion and the distant metastasis (8). Chemical or thermal ablation, radiotherapy, transcatheter arterial chemoembolization, drug treatment are palliative therapeutic modalities for advanced liver cancer, but they still have many disadvantages, such as impaired organic function, bone marrow suppression and drug resistance (5).

As one of the main components of antitumor traditional Chinese medicine from toad venom, bufalin has been confirmed to have antitumor activity, which has an obviously inhibiting role in various kinds of blood and solid malignancies including liver cancer (9). In recent research it is shown that bufalin is able to reverse multi-drug resistance of HCC cells and strengthen the ability of sorafenib to suppress proliferation of HCC cells $(10,11)$. Our preliminary study indicated that bufalin could restrain the proliferation of human hepatoma BEL-7402 cells in a time- and dosedependent manner and the $\mathrm{IC}_{50}$ value of $72 \mathrm{~h}$ was $0.085 \mu \mathrm{g} /$ $\mathrm{ml}$. Yet, the mechanism of inhibiting the proliferation, invasion and metastasis of HCC cells by bufalin still remains 
unclear (12). The abnormal activation of $\mathrm{Wnt} / \beta$-catenin signaling pathway plays an important role in the occurrence and development of many tumors (13). Multiple antitumor drugs resist HCC cells through regulating the activity of Wnt/ $\beta$-catenin signaling pathway (14-16). The anti-HCC cell effect of bufalin correlating with the abnormal activation of Wnt/ $\beta$-catenin signaling pathway is unclear.

The expression of associated factors in Wnt/ $\beta$-catenin signaling pathway of human hepatoma BEL-7402 cells, $\alpha$-fetoprotein (AFP) and albumin (ALB) protein expression are, respectively, detected after bufalin is used in vitro. The present study aims to reveal the mechanism of bufalin against the proliferation, invasion and metastasis of HCC cells.

\section{Materials and methods}

Materials. Bufalin was purchased from Shanghai Bogoo Biotechnology Co., Ltd. (Shanghai, China). Human hepatoma carcinoma cell line BEL-7402 were provided by the Institute of Biochemistry and Cell Biology (SIBS; Shanghai, China). RPMI-1640 medium (Gibco, Grand Island, NY, USA), fetal bovine serum (FBS; Hangzhou Tianhang Biological Technology, Co., Ltd., Hangzhou, China), trypsin (Sigma, St. Louis, MO, USA), $0.1 \%$ crystal violet staining solution (Beyotime Institute of Biotechnology, Shanghai, China) and Matrigel basement membrane matrix (BD Biosciences, Bedford, MA, USA) were purchased. Adenomatous polyposis coli (APC), E-cadherin, cyclin D1, metalloproteinase-7 (MMP-7), cyclooxygenase-2 (COX-2), GSK-3 $\beta$, $\beta$-catenin, p-GSK-3 $\beta$ Ser9, AFP and ALB monoclonal antibodies were purchased from Bioworld Technology Inc. (St. Louis Park, MN, USA); $\beta$-actin antibody was purchased from Cell Signaling Technology (Danvers, MA, USA). Other materials including the cell lysis solution containing protease inhibitors (Beyotime Institute of Biotechnology), BCA protein quantitative kit (Shanghai Weiao Biotech, Ltd., Shanghai, China), 5X loading buffer (Shanghai Weiao Biotech), Western blocking solution (Shanghai Weiao Biotech), IgG (H+L) (HRP-labeled goat anti-rabbit IgG) (Beyotime Institute of Biotechnology); Triton (Solabio, Beijin, China), fluorescent-labeled goat antirabbit IgG (Jackson ImmunoResearch Labs, West Grove, PA, USA), dihydrochloride (DAPI; Beyotime Institute of Biotechnology) were purchased.

Cell cultures. BEL-7402 cells were cultured in RPMI-1640 medium containing $10 \%$ fetal bovine serum in the incubator of $37^{\circ} \mathrm{C}$, saturated humidity and $5 \% \mathrm{CO}_{2}$ in vitro.

Clony formation assay. BEL-7402 cells growing in $\log$ phase were seeded into $60-\mathrm{mm}$ dishes at a density of 2,000 cells/dish. After cultured for $24 \mathrm{~h}$, the cells were treated with bufalin $(0.05 \mu \mathrm{g} / \mathrm{ml})$ in vitro. The medium was replaced with fresh medium containing bufalin every 3 days. Nine days later, the culture medium was removed and cell colonies were stained with $0.1 \%$ crystal violet. Colonies including $<15$ cells and faintly stained cells were ignored. The number of colonies in 10 random fields was counted under an inverted microscope (Carl Zeiss, Oberkochen, Germany).
Cell migration assay. After cultured with bufalin $(0.085 \mu \mathrm{g} / \mathrm{ml})$ for $72 \mathrm{~h}$ and with serum-free RPMI-1640 medium for $12 \mathrm{~h}$ in vitro, BEL-7402 cells were harvested and prepared to $1 \times 10 \% \mathrm{ml}$ cell suspension in serum-free RPMI-1640 medium. RPMI-1640 medium (600 $\mu \mathrm{l}$ ) with $10 \%$ fetal calf serum (FBS) was added into the lower chamber of the Transwell (Corning Incorporated, Corning, NY, USA), and $100 \mu \mathrm{l}$ of cell suspension was added into the upper chamber. The experiment was performed in triplicate. After incubated at $37^{\circ} \mathrm{C}$ with $5 \% \mathrm{CO}_{2}$ for $24 \mathrm{~h}$, the cells that did not migrate through the membrane were gently removed. Cells that migrated through the membrane were stained with $0.1 \%$ crystal violet. Six fields were randomly selected and observed under the inverted microscope for stained cell number counting and image collection.

Cell invasion assay. After the culture with bufalin $(0.085 \mu \mathrm{g} / \mathrm{ml})$ for $72 \mathrm{~h}$ and with serum-free RPMI-1640 for $12 \mathrm{~h}$ in vitro, BEL-7402 cells were harvested and prepared to $1 \times 10^{6} / \mathrm{ml}$ cell suspension in serum-free RPMI-1640 medium. RPMI-1640 $(600 \mu \mathrm{l})$ with $10 \%$ FBS was added into the lower chamber of the Transwell, and $100 \mu \mathrm{l}$ of cell suspension was added into the upper chamber with a filter coated with $100 \mu$ l Matrigel at 1:8 dilutions in serum-free medium. The experiment was performed in triplicate. After incubated at $37^{\circ} \mathrm{C}$ with $5 \% \mathrm{CO}_{2}$ for $48 \mathrm{~h}$, the cells that did not invade the membrane were gently removed. Cells that invaded the membrane were stained with $0.1 \%$ crystal violet. Six fields were randomly selected and observed under an inverted microscope for counting the cell number of stained cells and image collection.

Quantitative analysis of proteins in Wnt/ $\beta$-catenin signaling pathway and E-cadherin/ $\beta$-catenin complex in BEL-7402 cells. BEL-7402 cells were treated with bufalin $(0.085 \mu \mathrm{g} / \mathrm{ml})$ for $72 \mathrm{~h}$, then rinsed with ice-cold 0.01 M PBS, cell lysis solution containing protease inhibitors was added. After cell lysis, lysis suspension was collected and centrifuged at $4^{\circ} \mathrm{C}$ with speed of $16,000 \mathrm{x} g$ for $15 \mathrm{~min}$ to draw off supernatant solution. Afterwards, microplate reader (Bio-Rad Laboratories Inc., Hercules, CA, USA) was used to measure the absorbance value of protein samples and the reference standard samples in BCA protein quantitative kit at $\sim 562 \mathrm{~nm}$, and then protein contents in various groups were calculated. The protein content in unit volume of extract was balanced, using 0.01 M PBS as supplement. Protein solution was mixed with $5 X$ loading buffer at 1:4 ratio, then the protein mixture was denatured in water bath at $100^{\circ} \mathrm{C}$ for $5 \mathrm{~min}$ in the various groups. Electrophoretic separation was conducted using $10 \%$ SDS polyacrylamide gels. The protein bands after electrophoresis were transferred to polyvinylidene fluoride (PVDF) membrane which was blocked with western blocking solution for $1 \mathrm{~h}$. Then this membrane was, respectively, incubated in monoclonal antibodies APC (1:500), E-cadherin (1:500), cyclin D1 (1:500), MMP-7 (1:500), COX-2 (1:500), GSK-3 $\beta$ (1:500), $\beta$-catenin (1:500), p-GSK-3 $\beta$ Ser9 $(1: 500)$ and $\beta$-actin $(1: 1,000)$ at $4^{\circ} \mathrm{C}$ for $18 \mathrm{~h}$. Then, the membrane was rinsed with PBST three times and incubated in $\operatorname{IgG}(\mathrm{H}+\mathrm{L})$ at $37^{\circ} \mathrm{C}$ for $2 \mathrm{~h}$. The PVDF membrane was again rinsed with PBST three times prior to treatment with enhanced chemiluminescence western blotting detection kit (Amersham Biosciencse, Piscataway, NJ, USA). The images of protein 
Table I. Effect of bufalin on the protein expression in Wnt/ $\beta$-catenin signal pathway and E-cadherin/ $\beta$-catenin complex in BEL-7402 cells (gray value, mean $\pm \mathrm{SD}, \mathrm{n}=3$ ).

\begin{tabular}{|c|c|c|c|c|}
\hline Protein/parameter & Bufalin group & Control group & t-value & P-value \\
\hline$\beta$-catenin & $1328 \pm 23^{\mathrm{a}}$ & $2302 \pm 35$ & 40.281 & $<0.001$ \\
\hline p-GSK-3 $\beta$ Ser 9 & $1254 \pm 38^{\mathrm{a}}$ & $2017 \pm 34$ & 25.918 & $<0.001$ \\
\hline E-cadherin & $3968 \pm 28^{a}$ & $2077 \pm 46$ & -60.821 & $<0.001$ \\
\hline $\mathrm{APC}$ & $2109 \pm 45$ & $2034 \pm 64$ & -1.660 & 0.172 \\
\hline GSK-3 $\beta$ & $2798 \pm 37$ & $2775 \pm 26$ & -0.881 & 0.428 \\
\hline MMP-7 & $1224 \pm 41^{\mathrm{a}}$ & $2187 \pm 55$ & 24.314 & $<0.001$ \\
\hline $\mathrm{COX}-2$ & $1021 \pm 61^{\mathrm{a}}$ & $1908 \pm 43$ & 20.585 & $<0.001$ \\
\hline Cyclin D1 & $1814 \pm 44^{\mathrm{a}}$ & $2987 \pm 45$ & 32.282 & $<0.001$ \\
\hline
\end{tabular}

${ }^{\text {aP }}<0.01$ vs. the control group.

bands were visualized on X-ray film (Kodak, Rochester, NY, USA) and analyzed with the Bio-Rad Quantity One software (Bio-Rad Laboratories) 3 times.

Localization of proteins in Wnt/ $\beta$-catenin signaling pathway and E-cadherin/ $\beta$-catenin complex in BEL-7402 cells. BEL-7402 cells were treated with bufalin $(0.085 \mu \mathrm{g} / \mathrm{ml})$ for $72 \mathrm{~h}$ in vitro, and then cells were treated with PBS-Triton solution $(40 \mathrm{ml} \mathrm{PBS}+0.1 \%$ Triton $50 \mu \mathrm{l})$, rinsed with $0.01 \mathrm{M}$ PBS. The processed cells were, respectively, incubated with rabbit anti-human monoclonal antibodies APC (1:100), E-cadherin (1:100), cyclin D1 (1:100), MMP-7 (1:100), COX-2 (1:100), GSK-3 $\beta$ (1:100), $\beta$-catenin (1:100) and p-GSK-3 $\beta$ Ser9 $(1: 100)$ at $4^{\circ} \mathrm{C}$ for $18 \mathrm{~h}$. Afterwards, the cells were rinsed and incubated with fluorescent-labeled goat anti-rabbit IgG at $37^{\circ} \mathrm{C}$ for $2 \mathrm{~h}$. The cell nucleus was stained with DAPI, then observed by a fluorescent inverted microscope (Carl Zeiss) for image collection and analysis.

Quantitative analysis of $A F P$ and $A L B$ expression in $B E L-7402$ cells. BEL-7402 cells were treated with bufalin $(0.085 \mu \mathrm{g} / \mathrm{ml})$ for 1 week, then rinsed with ice-cold $0.01 \mathrm{M}$ $\mathrm{PBS}$, and cell lysis solution containing protease inhibitors was added. After cell lysis, lysis suspension was collected and centrifuged at $4^{\circ} \mathrm{C}$ with speed of $16,000 \mathrm{x}$ g for 15 min to draw off supernatant solution. Then, microplate reader was used to measure the absorbance value of protein samples and the reference standard samples in BCA protein quantitative kit at $\sim 562 \mathrm{~nm}$, and then protein contents in various groups were calculated. The protein content in unit volume of extract was balanced, using 0.01 M PBS as supplement. Protein solution was mixed with $5 \mathrm{X}$ loading buffer at 1:4 ratio, then the protein mixture was denatured in water bath at $100^{\circ} \mathrm{C}$ for $5 \mathrm{~min}$ in various group. Electrophoretic separation was conducted using $10 \%$ SDS polyacrylamide gels. The protein bands after electrophoresis were transferred to PVDF membrane which was blocked with western blocking solution for $1 \mathrm{~h}$. The membrane was then, respectively, incubated in monoclonal antibodies AFP (1:500), ALB (1:500) and $\beta$-actin $(1: 1,000)$ at $4^{\circ} \mathrm{C}$ for $18 \mathrm{~h}$. The membrane was rinsed with PBST three times and incubated in $\operatorname{IgG}(\mathrm{H}+\mathrm{L})$ at $37^{\circ} \mathrm{C}$ for $2 \mathrm{~h}$. The PVDF membrane was again rinsed with PBST three times prior to photographic developing and fixing. Digital images of protein bands were obtained using ChemiDoc system and analyzed with the Bio-Rad Quantity One software 3 times.

Statistical analysis. The SPSS 19.0 statistical software (IBM, Armonk, NY, USA) was used for statistical processing. Quantitative variables were expressed by mean \pm SD and analyzed with t-test. P-value $<0.05$ was considered statistically significant.

\section{Results}

Effect of bufalin on colony formation of HCC cells. The number of the colonies in the bufalin group $(0.05 \mu \mathrm{g} / \mathrm{ml})$ was lower than that of control group (Fig. 1A). The colonies formed in bufalin group $(0.05 \mu \mathrm{g} / \mathrm{ml})$ and the cells in colonies of bufalin group were clearly less than those of control group under microscope (Fig. 1B). Quantitative analysis of the colonies showed that compared with the control group, the colony formation ability of BEL-7402 cells was significantly inhibited by bufalin $(\mathrm{P}<0.05$; Fig. $1 \mathrm{C})$.

Influence of bufalin on migration and invasion of HCC cells. Compared with the control group, the migration and invasion ability of the BEL-7402 cells was significantly inhibited by bufalin (Fig. 2A and C). Quantitative analysis of the migrating and invasive cells showed that compared with the control group, the migration and invasion number of BEL-7402 cells having been treated with bufalin $(0.085 \mu \mathrm{g} / \mathrm{ml})$ for $72 \mathrm{~h}$ was reduced significantly (both $\mathrm{P}<0.05$; Fig. $2 \mathrm{~B}$ and $\mathrm{D}$ ).

Effect of bufalin on the protein expression and localization of $\beta$-catenin in HCC cells. Compared with the control group, the protein expression of $\beta$-catenin in BEL-7402 cells of bufalin group after exposure to bufalin $(0.085 \mu \mathrm{g} / \mathrm{ml})$ for $72 \mathrm{~h}$ decreased significantly $(\mathrm{P}<0.05)$ (Table I and Fig. 3A).

The immunofluorescence imaging showed that $\beta$-catenin mainly localized in the cytoplasm and nuclei of BEL-7402 cells in the control group. After exposure to bufalin $(0.085 \mu \mathrm{g} /$ $\mathrm{ml}$ ) for $72 \mathrm{~h}$, the fluorescence intensity of $\beta$-catenin increased 

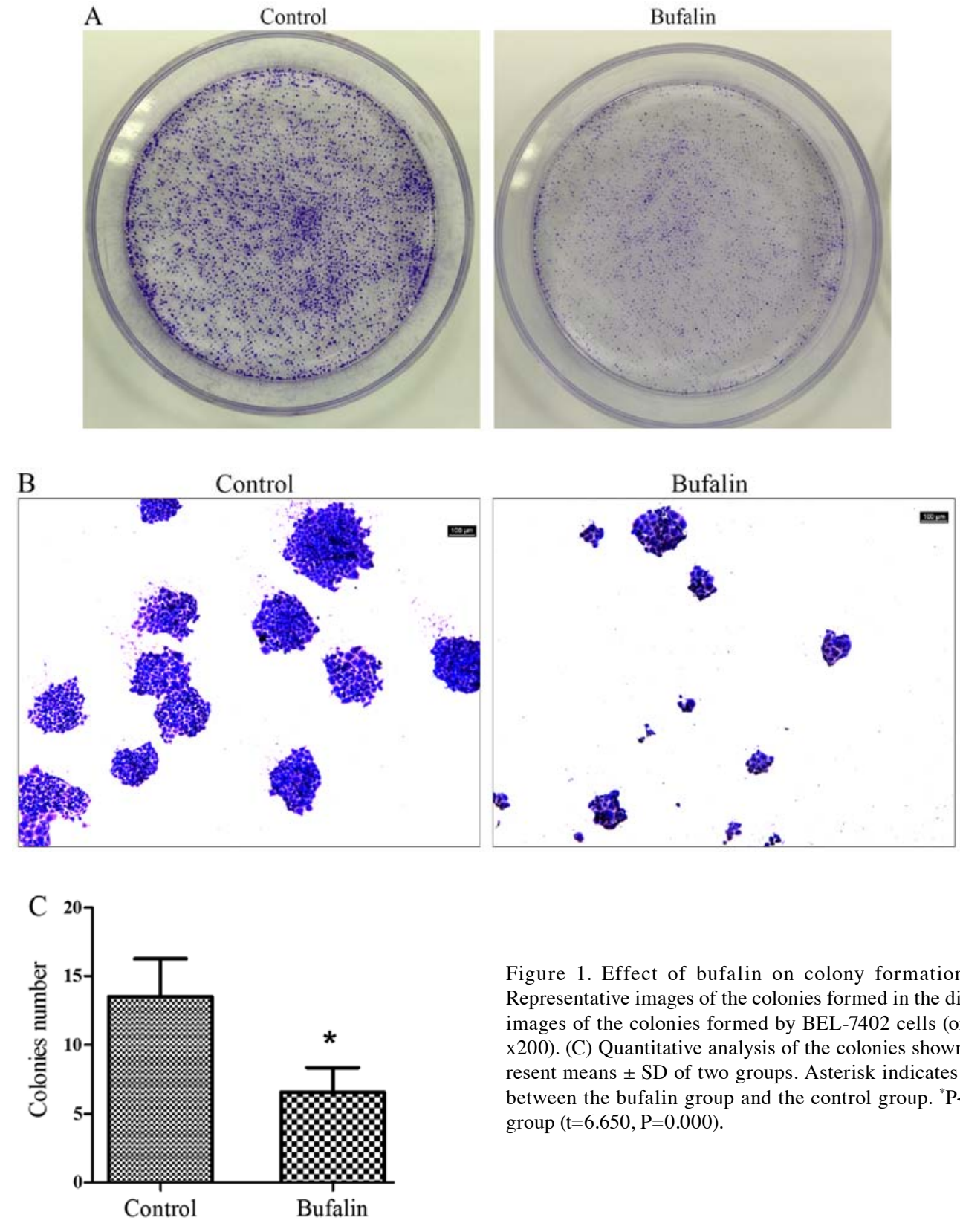

Figure 1. Effect of bufalin on colony formation of HCC cells. (A) Representative images of the colonies formed in the dish. (B) Representative images of the colonies formed by BEL-7402 cells (original magnification, x200). (C) Quantitative analysis of the colonies shown in (B). The bars represent means \pm SD of two groups. Asterisk indicates significant difference between the bufalin group and the control group. ${ }^{*} \mathrm{P}<0.001$ vs. the control group $(\mathrm{t}=6.650, \mathrm{P}=0.000)$.

significantly on cell membrane, whereas the fluorescence intensity of $\beta$-catenin decreased in the cytoplasm and nuclei of BEL-7402 cells (Fig. 3B).

Effect of bufalin on the protein expression of $p-G S K-3 \beta$ Ser9, E-cadherin, APC and GSK-3 $\beta$ in wnt/ $\beta$-catenin signal pathway of HCC cells. Compared with the control group, the protein expression of p-GSK-3 $\beta$ Ser9 in BEL-7402 cells of the bufalin group after exposure to bufalin $(0.085 \mu \mathrm{g} / \mathrm{ml})$ for $72 \mathrm{~h}$ decreased significantly. The protein expression of E-cadherin in BEL-7402 cells increased significantly after bufalin treatment $(\mathrm{P}<0.05)$. The protein expression of APC and GSK-3 $\beta$ in BEL-7402 cells was not significantly different between the control group and the bufalin group $(\mathrm{P}>0.05)$ (Table I and Fig. 4A).

The immunofluorescence imaging showed that compared with the control group, the fluorescence intensity of p-GSK-3 $\beta$ Ser9 in the cytoplasm decreased (Fig. 4B), and the fluorescence intensity of E-cadherin on cell membrane increased after exposure to bufalin $(0.085 \mu \mathrm{g} / \mathrm{ml})$ for $72 \mathrm{~h}$ (Fig. 4C). Whereas the fluorescence intensity of APC and GSK-3 $\beta$ in cytoplasm was, respectively, not significantly different between the bufalin group and the control group (Fig. 4D and E).

Effect of bufalin on the protein expression of MMP-7, COX-2, and cyclin DI in the downstream molecules of $w n t / \beta$-catenin signal pathway in HCC cells. Compared with the control group, the protein expression of MMP-7, COX-2 and cyclin D1 in BEL-7402 cells of bufalin group after exposure to bufalin $(0.085 \mu \mathrm{g} / \mathrm{ml})$ for $72 \mathrm{~h}$ decreased significantly $(\mathrm{P}<0.05)$ (Table I and Fig. 5A).

The immunofluorescence imaging showed that when compared with the control group, the fluorescence intensity of MMP-7, COX-2 and cyclin D1 in cytoplasm of BEL-7402 cells decreased after exposure to bufalin $(0.085 \mu \mathrm{g} / \mathrm{ml})$ for 72 h (Fig. 5B-D). 

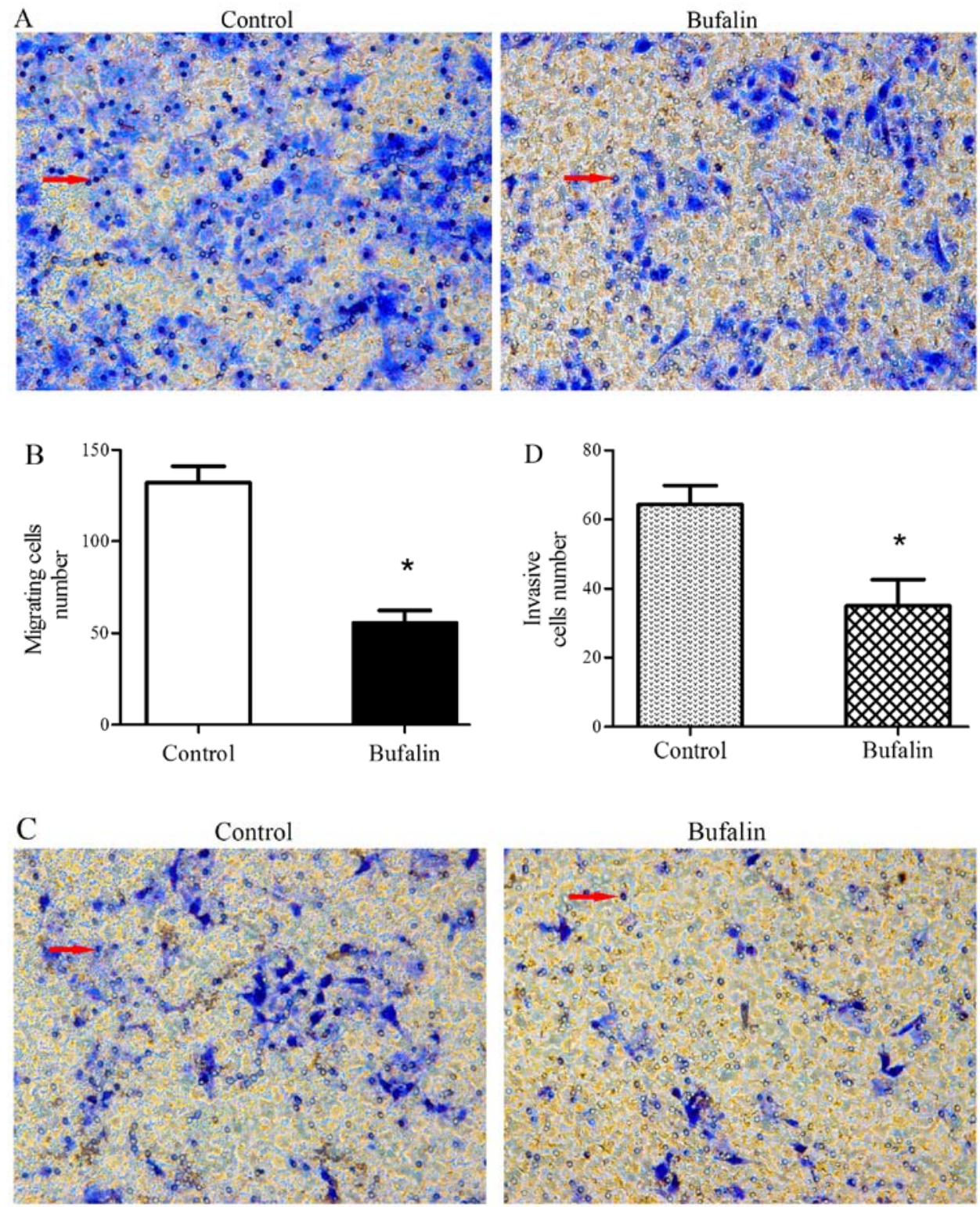

Figure 2. Influence of bufalin on migration and invasion of HCC cells. (A) Representative images of the BEL-7402 cells migrating to the underside of the polycarbonate membrane (cell marked with red arrow) (original magnification, x200). (B) Quantitative analysis of the migrating cells shown in (A). The bars represent means \pm SD of two groups. Asterisks indicate significant difference between the bufalin group and the control group. (C) Representative images of the BEL-7402 cells invading to the underside of the polycarbonate membrane (cell marked with red arrow) (original magnification, x200). (D) Quantitative analysis of the invasive cells shown in (C). The bars represent means \pm SD of two groups. Asterisk indicates significant difference between bufalin group and control group. ${ }^{*} \mathrm{P}<0.01$ vs. the control group ( $\left.\mathrm{t}=11.717, \mathrm{P}=0.0003\right) ;{ }^{*} \mathrm{P}<0.01$ vs. the control group $(\mathrm{t}=5.437, \mathrm{P}=0.0056)$.

Effect of bufalin on the protein expression of AFP and ALB in $H C C$ cells. Compared with the control group, the protein expression of AFP in BEL-7402 cells of bufalin group after exposure to bufalin $(0.085 \mu \mathrm{g} / \mathrm{ml})$ for 1 week obviously decreased, and the expression levels of ALB increased significantly (both $\mathrm{P}<0.05)$ (Table II and Fig. 6).

\section{Discussion}

Intracellular signal transduction pathway is a complex network system that transduces extracellular signals into intracelluar downstream molecules. However, these accurately regulating signal networks occur some abnormal change in malignant tumor cells as a result of gene mutation, which eventually results in a series of changes in cellular metabolism and the occurrence of new features. The change of cell signaling pathway can give rise to various malignant behavior, such as uncontrollable proliferation, anti-apoptosis, invasion and metastasis of tumor cells $(17,18)$.

Wnt signaling pathway plays a crucial role in embryonic development and tissue stability (19). To date, Wnt signaling pathway is classified into two categories: canonical Wnt pathway and non-canonical Wnt pathway. The activation of non-canonical Wnt pathway does not rely on the participation of $\beta$-catenin, including $\mathrm{Wnt} / \mathrm{Ca}^{2+}$ pathway and $\mathrm{Wnt} / \mathrm{PCP}$ pathway (20). Wnt/ $\beta$-catenin pathway, known as a canonical Wnt signaling pathway, consists of Wnt signaling ligands, Fz receptor family, and co-receptor lipoprotein receptorrelated proteins 5 and 6 (LRP5/6), disheveled (Dsh), axin, $\beta$-catenin, APC, casein kinase 1a and GSK-3 $\beta$. Among them, 
A

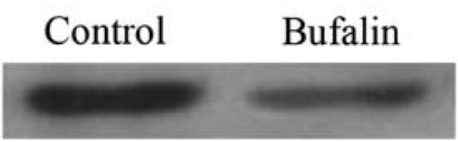

ß-actin
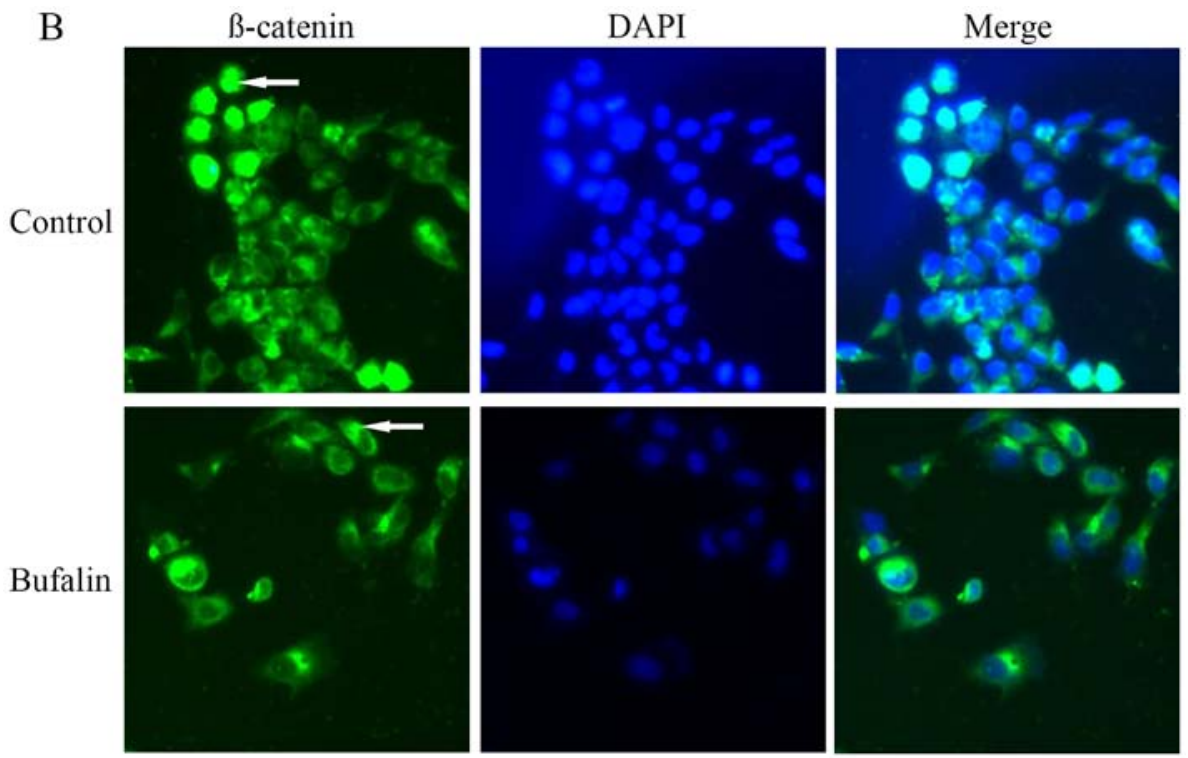

Figure 3. Effect of bufalin on the expression of $\beta$-catenin in BEL-7402 cells. (A) The protein expression levels of $\beta$-catenin in bufalin group and control group. (B) Representative immunofluorescence micrographs of BEL-7402 cells stained with antibodies against $\beta$-catenin ( $\beta$-catenin marked with white arrow) (original magnification, $\mathrm{x} 200$ ).

Table II. Effect of bufalin on the protein expression of AFP and ALB in BEL-7402 cells (gray value, mean \pm SD, $n=3$ ).

\begin{tabular}{lrrrr}
\hline Protein/parameter & Bufalin group & Control group & t-value & P-value \\
\hline AFP & $7341 \pm 643^{\mathrm{a}}$ & $11043 \pm 947$ & 5.605 & 0.005 \\
ALB & $10031 \pm 376^{\mathrm{a}}$ & $4752 \pm 470$ & 15.19 & $<0.001$ \\
\hline
\end{tabular}

${ }^{\text {a }}<0.01$ vs. the control group.

$\beta$-catenin acts as the key protein in function implementation of Wnt/ $\beta$-catenin signaling pathway, $\beta$-catenin accumulation in cytoplasm predicts that $\mathrm{Wnt} / \beta$-catenin pathway is in the activated state. In normal mature cells, due to lack of Wnt factor stimulation, most of $\beta$-catenin combines with E-cadherin on cell membrane, while a small amount of free $\beta$-catenin will be quickly phosphorylated in degradation complex (consisting of APC, axin and GSK-3 $\beta$ ), modified by ubiquitin and then hydrolyzed by protease. In this case, the quantity of free casein kinase 1a-catenin in cytoplasm usually remains at a very low level. As required in embryonic development or tissue regeneration, receptor complexes on cell membrane (including Fz receptor family and co-receptor LRP5/6) will combine with extracellular Wnt factors, and degrade the degradation complex under the mediation of Dsh protein. Thus, $\beta$-catenin will accumulate in cytoplasm and pass through the nuclear membrane to conjugate with transcription factor/lymphoid enhancer-binding factor (TCF/LEF) in the nucleus, then activate the transcription of downstream target protein genes that are related to cell proliferation, apoptosis, matrix dissolution and angiogenesis, such as cyclin D1, MMP-7, COX-2, c-myc, survivin and vascular endothelial growth factor (VEGF) (21-23). Among these downstream target proteins, the cyclin D1 can regulate and control the cell transformation from $\mathrm{G} 1$ phase to $\mathrm{S}$ phase to interfere with the process of cell proliferation, by combining with cyclin-dependent kinase and activating it in G1 phase (24). MMP-7, a member of the family of matrix metalloproteinases, is not only involved in various extracellular matrix lysis, but also can damage diversified tumor-suppressor compositions on the cell surface (25). COX-2 can suppress tumor cell apoptosis, promote tumor cell proliferation, stimulate matrix metalloproteinases production and enhance tumor cell invasion and metastasis abilities (26). The overexpression of cyclin D1, MMP-7 and COX-2 plays an important role in the proliferation, invasion and metastasis of liver cancer (27-29). 
A
E-cadherin

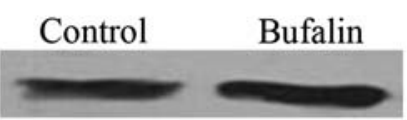

APC

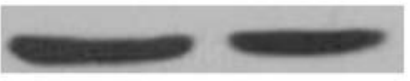

GSK-3ß

P-GSK-3ß

Ser9

B-actin
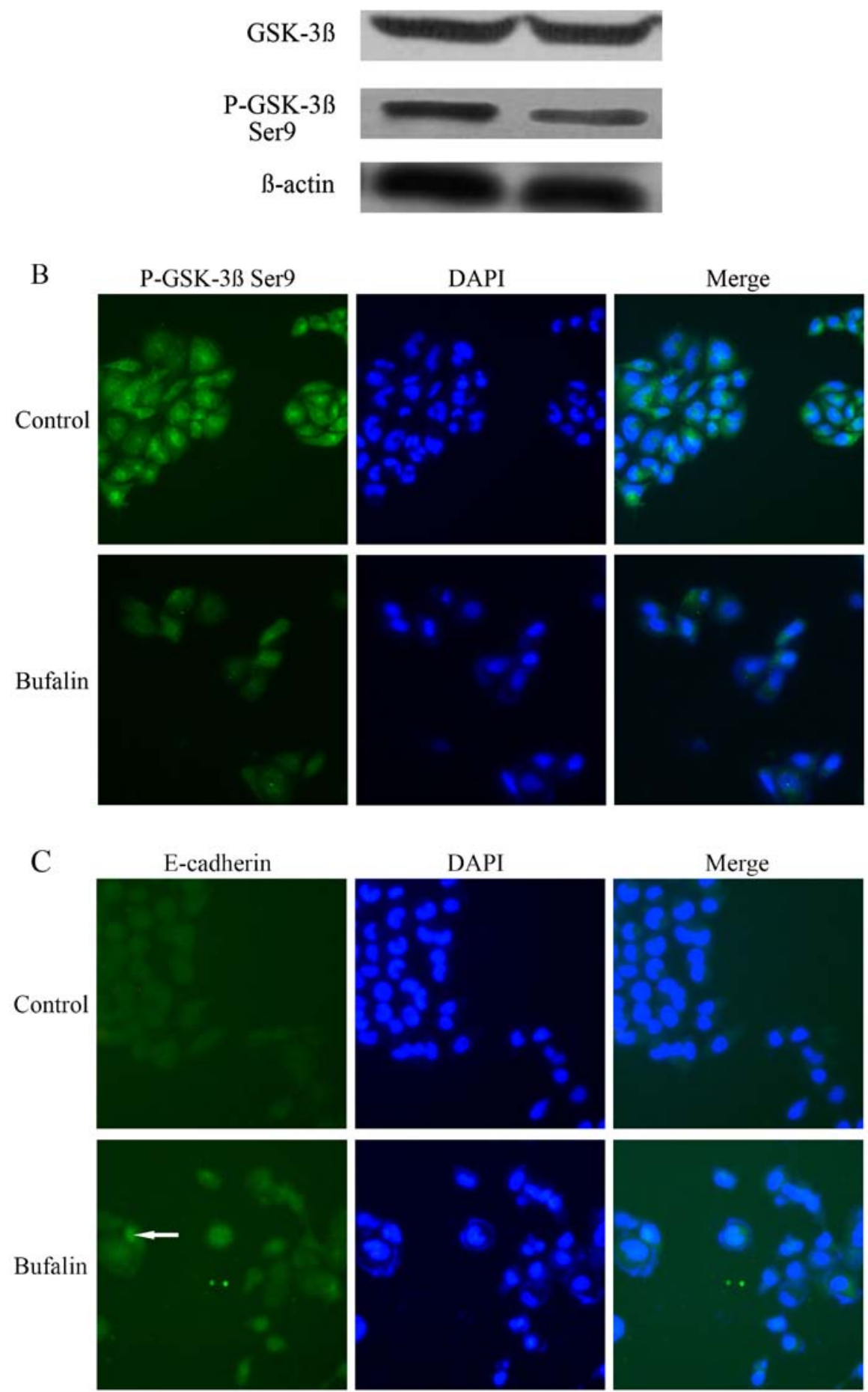

Figure 4. Effect of bufalin on the expression of p-GSK-3 $\beta$ Ser9, E-cadherin, APC and GSK-3 $\beta$ in BEL-7402 cells. (A) The protein expression levels of p-GSK-3 $\beta$ Ser9, E-cadherin, APC and GSK-3 $\beta$ in bufalin group and control group. (B and C) Representative immunofluorescence micrographs of BEL-7402 cells stained with antibodies against p-GSK-3 $\beta$ Ser9 and E-cadherin (E-cadherin marked with white arrow) (original magnification, x200).

The abnormal activation of Wnt/ $\beta$-catenin signal pathway has important biological effects on the occurrence and development of primary liver cancer (30). E-cadherin, mainly expressed in epithelial cells, can combine with intracellular $\beta$-catenin, and form a connected composite structure to participate in maintaining cell-cell and cell-extracellular 

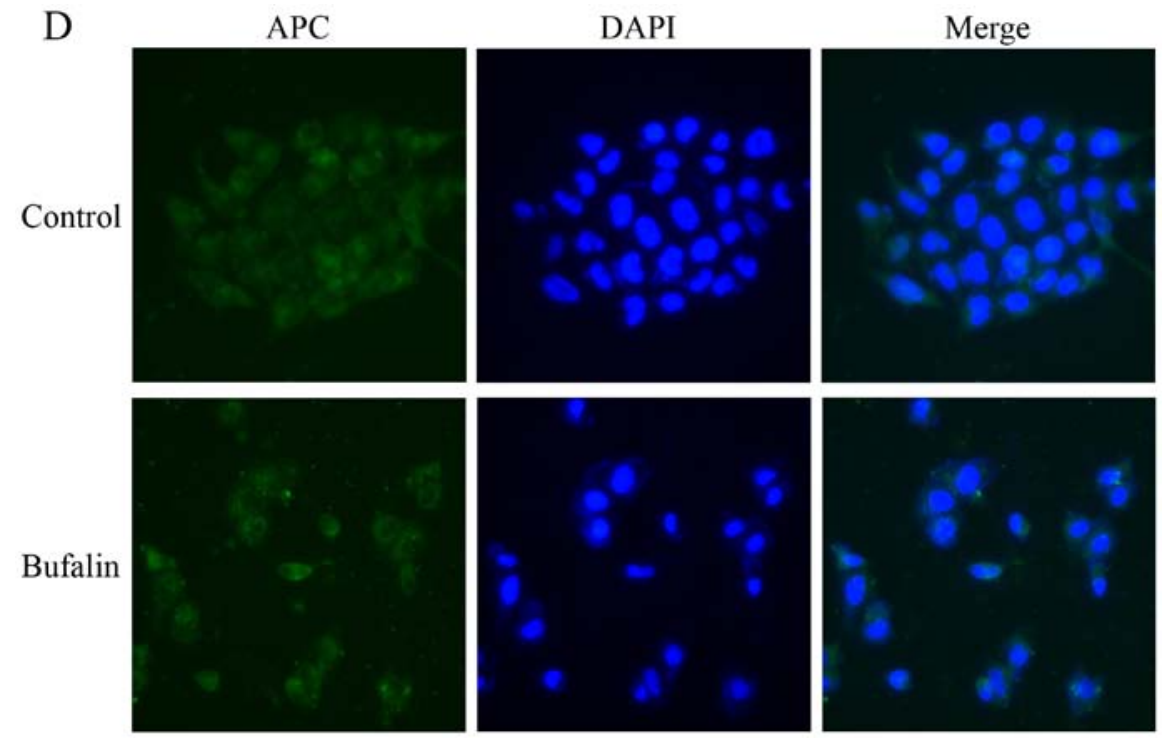

E

GSK- $3 \beta$
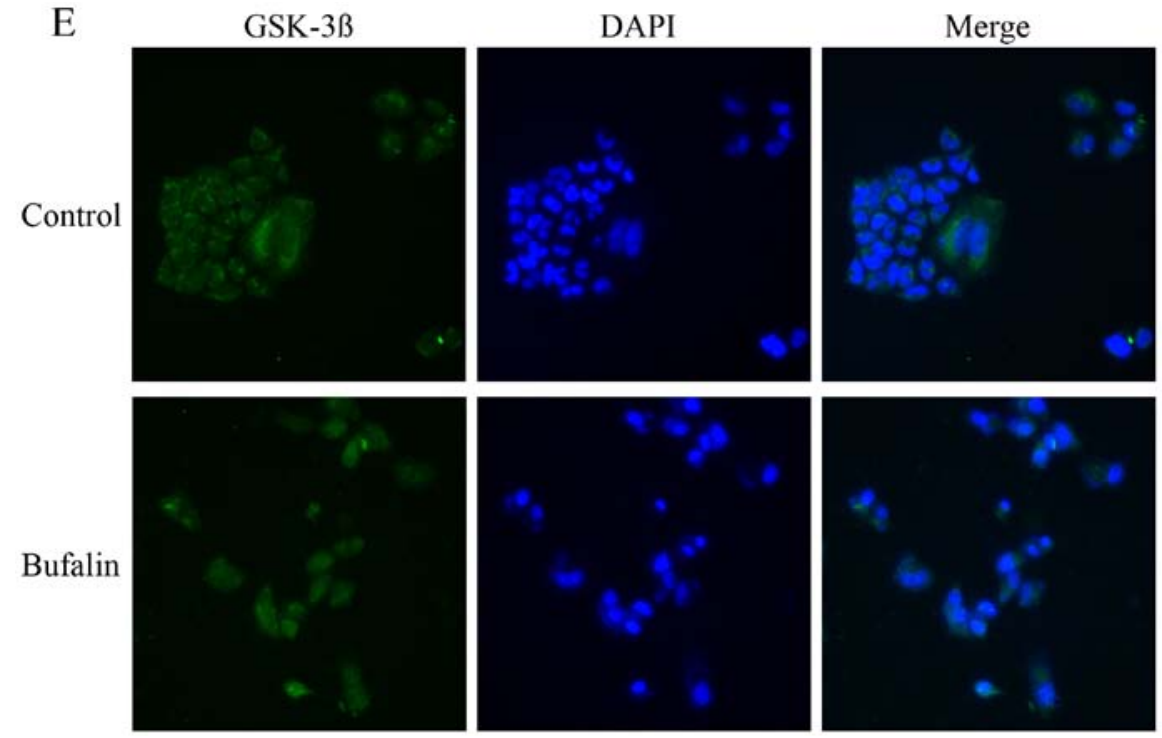

Figure 4. Continued. (D and E) Representative immunofluorescence micrographs of BEL-7402 cells stained with antibodies against APC and GSK-3 $\beta$ (original magnification, x200).

matrix adhesion stability. Therefore, the low expression of E-cadherin will result in a prominent increase of free $\beta$-catenin in the cytoplasm (31). GSK-3 $\beta$, the main function domain of complex degradation, possesses two phosphorylation sites with opposite regulating effects (including Tyr216 and Ser9). Phosphorylated Tyr216 can strengthen GSK-3 $\beta$ activity, while phosphorylated Ser9 site will lead to GSK-3 $\beta$ deactivation (32). The higher phosphorylation at GSK-3 $\beta$ ser9 site and lower expression of E-cadherin is regarded as major causes of activation of $\mathrm{Wnt} / \beta$-catenin pathway in $\mathrm{HCC}$ cells (33). In addition, epithelial-mesenchymal transition (EMT) also plays a key role in cancer metastasis process. As a phenotypic conversion, EMT promotes embryonic development and organ formation. However, EMT makes polar epithelial cells to convert into mesenchymal cells, increasing the loss of tight junctions between cells, promotes metastasis, invasion and enhances the anti-apoptotic ability of cells $(34,35)$.

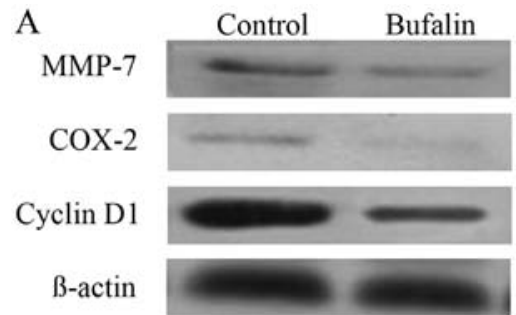

Figure 5. Effect of bufalin on the expression of MMP-7, COX-2 and cyclin D1 in BEL-7402 cells. (A) The protein expression levels of MMP-7, COX-2 and cyclin D1 in bufalin group and control group.

In the present study, through clone formation assay, we verified our previous experimental results that bufalin could inhibit HCC cell proliferation. In order to further explore the anti-HCC effect of bufalin, the tumor invasion and metastasis environment in vitro were established through Transwell 

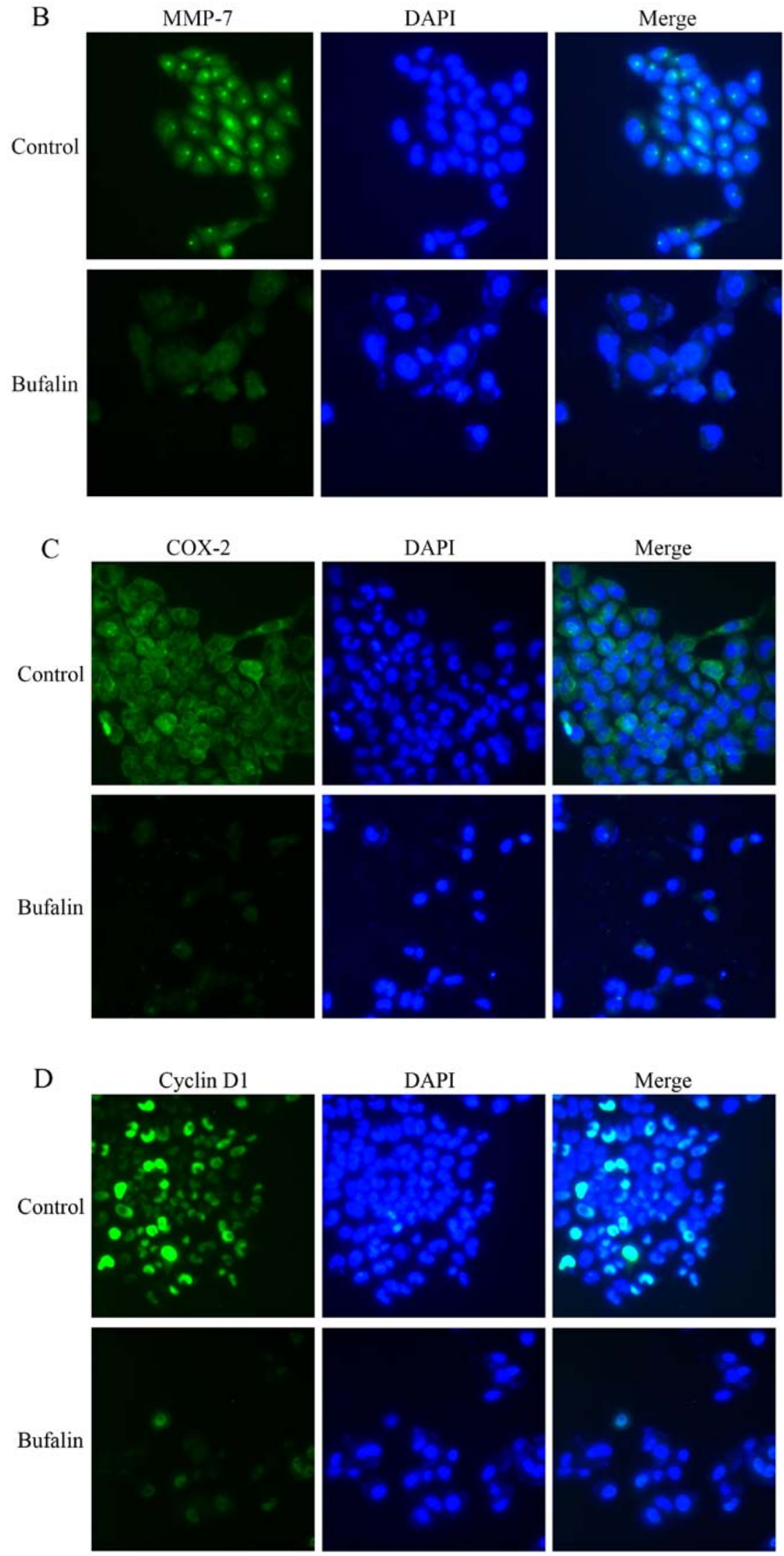

Figure 5. Continued. (B-D) Representative immunofluorescence micrographs of BEL-7402 cells stained with antibodies against MMP-7, COX-2 and cyclin D1 (original magnification, $\mathrm{x} 200$ ).

migration and invasion assay (36). The results showed that bufalin was able to inhibit the migration and invasion ability of BEl-7402 cells. Further experimental results showed that bufalin increased the local expression of $\beta$-catenin significantly 


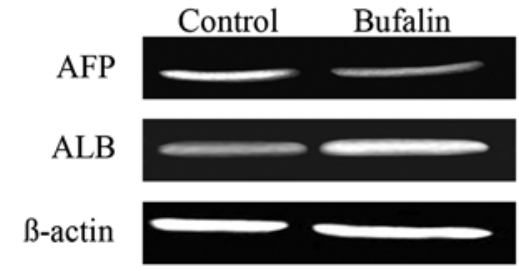

Figure 6. The protein expression levels of AFP and ALB in BEL-7402 cells.

on cell membrane, whereas, decreased the local expression of $\beta$-catenin in the cytoplasm and the nuclei of BEL-7402 cells, decreased the expression of p-GSK-3 $\beta$ Ser9 in the cytoplasm, increase the expression of E-cadherin and $\beta$-catenin on the cell membrane of BEL-7402 cells, decreased the expression of cyclin D1, MMP-7 and COX-2 in cytoplasm of BEL-7402 cells. It indicated that bufalin could inhibit the phosphorylation of GSK-3 $\beta$ Ser9 site and translocation of $\beta$-catenin in HCC cells, then influenced the extranuclear signal transduction and endonuclear target molecules, ultimately resulting in lower expressions of cyclin D1, MMP-7 and COX-2 in HCC cells. It might be an important biological mechanism of bufalin by which it inhibits the HCC cell proliferation, invasion and metastasis. Since bufalin increased the expression of E-cadherin and $\beta$-catenin on the cell membrane, the quantity of E-cadherin/ $\beta$-catenin complex increased as well. The complex between cells is an important factor to maintain the stability of the epithelial cells, having an inhibitory effect on EMT during the metastasis of tumor cells (37). Based on considerable research, when the EMT of tumor cells are restricted, the invasion and metastasis ability of tumor cells markedly decrease (38-40). Thus, enhancing the stability between the membrane of epithelial cells and inhibiting the EMT are also important mechanisms by which bufalin inhibits the HCC cell invasion and migration.

AFP develops during fetal development, the AFP concentration decreases rapidly after birth. In normal adult, the AFP concentration is very low, and AFP gene is in a hermit state, but will be activated when high quantity of $\mathrm{HCC}$ cells appear. Thus, it is used widely in clinical diagnosis of $\mathrm{HCC}$, and it is an important malignant phenotype of HCC cells. The overexpression of AFP is often associated with HCC metastasis, vascular invasion, and other related malignant behavior $(41,42)$. In contrast with AFP, ALB produced by the liver cells has an important role in maintaining body's normal physiological activities (43). Determination of ALB synthesis reflects liver cell function and it is an indicator of liver cancer cell differentiation in vitro $(44,45)$. Recent studies have found that AFP can promote cell growth of HCC while ALB inhibits HCC cell proliferation $(46,47)$. After bufalin was added into HCC cells in vitro, the result showed that bufalin could significantly decrease expression of AFP, while bufalin increased expression of ALB in BEL-7402 cells. It indicates that bufalin reverses the cell malignant phenotype, promoting cell differentiation and maturation, and regulating the expression of AFP and ALB in BEL-7402 cells, thus, suggesting that bufalin could inhibit the malignant biological behavior of HCC cells.

In conclusion, metastasis of malignant tumors is a continuous complicated process, including the tumor growth in the original site, cells invading into the body circulation after EMT, and replantation into the new organ tissue from the circulatory system followed by proliferation $(48,49)$. Our research results show that by inhibiting GSK-3 $\beta$ Ser9 site phosphorylation, bufalin weakened the activity of the Wnt/ $\beta$ catenin signaling pathway. By increasing inter-membrane E-cadherin/ $\beta$-catenin complex, bufalin inhibited the EMT of HCC cells. It indicates that they are the key mechanisms of bufalin against cell proliferation, invasion and metastasis of HCC cells. However, due to poor water solubility, high toxicity, and short half-life the clinical application of bufalin is restricted (50). It is necessary to further develop and prepare the new drug dosage form of bufalin such as nano-drugs via combining bufalin with polymer nano-carrier, the new dosage form can not only reduce the bufalin toxicity, but also have slow-release and active targeting properties. The present study provide very important theoretical basis for further developing the new molecular targeted drugs aimed at specific site of the Wnt/ $\beta$-catenin signaling pathway. The new dosage form of bufalin and molecular targeted drugs will improve the antiHCC effects of bufalin.

\section{Acknowledgements}

The present study was supported by a grant from the Programs of Key Hepatic-Biliary-Pancreatic Surgery Foundation of Putuo District, Shanghai, China (no. 2012-B-162).

\section{References}

1. Song MJ and Bae SH: Newer treatments for advanced hepatocellular carcinoma. Korean J Intern Med 29: 149-155, 2014.

2. Wang Y, Shen Z, Zhu Z, Han R, Huai M and Huai M: Clinical values of AFP, GPC3 mRNA in peripheral blood for prediction of hepatocellular carcinoma recurrence following OLT: AFP, GPC3 mRNA for prediction of HCC. Hepat Mon 11: 195-199, 2011.

3. Zhao YJ, Ju Q and Li GC: Tumor markers for hepatocellular carcinoma. Mol Clin Oncol 1: 593-598, 2013.

4. Jo S and Shim HK: A patient who has survived for a long period with repeated radiotherapies for multifocal extrahepatic metastases from hepatocellular carcinoma. Radiat Oncol J 31: 267-272, 2013.

5. Lin S, Hoffmann K and Schemmer P: Treatment of hepatocellular carcinoma: A systematic review. Liver Cancer 1: 144-158, 2012.

6. Belghiti $J$ and Fuks D: Liver resection and transplantation in hepatocellular carcinoma. Liver Cancer 1: 71-82, 2012.

7. Vitale A, Volk M and Cillo U: Transplant benefit for patients with hepatocellular carcinoma. World J Gastroenterol 19: 9183-9188, 2013.

8. Chan SC: Liver transplantation for hepatocellular carcinoma. Liver Cancer 2: 338-344, 2013.

9. Yin PH, Liu X, Qiu YY, Cai JF, Qin JM, Zhu HR and Li Q: Anti-tumor activity and apoptosis-regulation mechanisms of bufalin in various cancers: New hope for cancer patients. Asian Pac J Cancer Prev 13: 5339-5343, 2012.

10. Gu W, Liu L, Fang FF, Huang F, Cheng BB and Li B: Reversal effect of bufalin on multidrug resistance in human hepatocellular carcinoma BEL-7402/5-FU cells. Oncol Rep 31: 216-222, 2014.

11. Gao Y, Li HX, Xu LT, Wang P, Xu LY, Cohen L, Yang PY, Gu K and Meng ZQ: Bufalin enhances the anti-proliferative effect of sorafenib on human hepatocellular carcinoma cells through downregulation of ERK. Mol Biol Rep 39: 1683-1689, 2012.

12. Gai JQ, Qin JM and Fan YZ: The effect of bufalin on proliferation and invasion of human liver cancer cells. World Chin J Digestology 22: 1921-1927, 2014. 
13. Pandurangan AK: Potential targets for prevention of colorectal cancer: A focus on PI3K/Akt/mTOR and Wnt pathways. Asian Pac J Cancer Prev 14: 2201-2205, 2013.

14. Xu MX, Zhao L, Deng C, Yang L, Wang Y, Guo T, Li L, Lin J and Zhang L: Curcumin suppresses proliferation and induces apoptosis of human hepatocellular carcinoma cells via the wnt signaling pathway. Int J Oncol 43: 1951-1959, 2013.

15. Wang F, He L, Dai WQ, Xu YP, Wu D, Lin CL, Wu SM, Cheng P, Zhang Y, Shen M, et al: Salinomycin inhibits proliferation and induces apoptosis of human hepatocellular carcinoma cells in vitro and in vivo. PLoS One 7: e50638, 2012.

16. Thompson MD, Dar MJ and Monga SP: Pegylated interferon alpha targets Wnt signaling by inducing nuclear export of $\beta$-catenin. J Hepatol 54: 506-512, 2011.

17. Cairns RA, Harris IS and Mak TW: Regulation of cancer cell metabolism. Nat Rev Cancer 11: 85-95, 2011.

18. Bachmann J, Raue A, Schilling M, Becker V, Timmer J and Klingmüller U: Predictive mathematical models of cancer signalling pathways. J Intern Med 271: 155-165, 2012.

19. Di Maio A, Setar L, Tiozzo S and De Tomaso AW: Wnt affects symmetry and morphogenesis during post-embryonic development in colonial chordates. Evodevo 6: 17, 2015.

20. Sastre-Perona A and Santisteban P: Role of the wnt pathway in thyroid cancer. Front Endocrinol (Lausanne) 3: 31, 2012.

21. Saito-Diaz K, Chen TW, Wang X, Thorne CA, Wallace HA, Page-McCaw A and Lee E: The way Wnt works: Components and mechanism. Growth Factors 31: 1-31, 2013.

22. Ren S, Johnson BG, Kida Y, Ip C, Davidson KC, Lin SL, Kobayashi A, Lang RA, Hadjantonakis AK, Moon RT, et al: LRP-6 is a coreceptor for multiple fibrogenic signaling pathways in pericytes and myofibroblasts that are inhibited by DKK-1. Proc Natl Acad Sci USA 110: 1440-1445, 2013.

23. Fuchs SY, Ougolkov AV, Spiegelman VS and Minamoto T: Oncogenic beta-catenin signaling networks in colorectal cancer. Cell Cycle 4: 1522-1539, 2005.

24. Nagasundaram N, Hailong Z, Jiming L, Karthick V, George Priya Doss C, Chirangib C and Luonan C: Analysing the effect of mutation on protein function and discovering potential inhibitors of CDK4: Molecular modelling and dynamics studies. PLoS One 10: e0133969, 2015

25. Wu J, Guan X, Zhang K, Li YT, Bai P and Wu J: A/G polymorphism of matrix metalloproteinase 7 gene promoter region and cancer risk: A meta-analysis. Biomed Rep 1: 792-796, 2013.

26. Wu KK, Cheng HH and Chang TC: 5-methoxyindole metabolites of L-tryptophan: Control of COX-2 expression, inflammation and tumorigenesis. J Biomed Sci 21: 17, 2014.

27. Lee MJ, Xu DY, Li H, Yu GR, Leem SH, Chu IS, Kim IH and Kim DG: Pro-oncogenic potential of NM23-H2 in hepatocellular carcinoma. Exp Mol Med 44: 214-224, 2012

28. Chen L, Li M, Li Q, Wang CJ and Xie SQ: DKK1 promotes hepatocellular carcinoma cell migration and invasion through $\beta$-catenin/MMP7 signaling pathway. Mol Cancer 12: 157, 2013.

29. Sui W, Zhang Y, Wang Z, Wang Z, Jia Q, Wu L and Zhang W: Antitumor effect of a selective COX-2 inhibitor, celecoxib, may be attributed to angiogenesis inhibition through modulating the PTEN/PI3K/Akt/HIF-1 pathway in an $\mathrm{H}_{22}$ murine hepatocarcinoma model. Oncol Rep 31: 2252-2260, 2014.

30. Wands JR and Kim M: WNT/ $\beta$-catenin signaling and hepatocellular carcinoma. Hepatology 60: 452-454, 2014.

31. Somorjai IM and Martinez-Arias A: Wingless signalling alters the levels, subcellular distribution and dynamics of Armadillo and E-cadherin in third instar larval wing imaginal discs. PLoS One 3: e2893, 2008

32. Liu W, Wang H, Wang Y, Li H and Ji L: Metabolic factorstriggered inflammatory response drives antidepressant effects of exercise in CUMS rats. Psychiatry Res 228: 257-264, 2015.

33. Wolfe A, Thomas A, Edwards G, Jaseja R, Guo GL and Apte U: Increased activation of the $\mathrm{Wnt} / \beta$-catenin pathway in spontaneous hepatocellular carcinoma observed in farnesoid X receptor knockout mice. J Pharmacol Exp Ther 338: 12-21, 2011.
34. Hou KZ, Fu ZQ and Gong H: Chemokine ligand 20 enhances progression of hepatocellular carcinoma via epithelial-mesenchymal transition. World J Gastroenterol 21: 475-483, 2015.

35. Kim HJ, Choi WJ and Lee CH: Phosphorylation and reorganization of keratin networks: Implications for carcinogenesis and epithelial mesenchymal transition. Biomol Ther (Seoul) 23 301-312, 2015.

36. Wei X, Wang J, He J, Ma B and Chen J: Biological characteristics of $\mathrm{CD} 133^{+}$cancer stem cells derived from human laryngeal carcinoma cell line. Int J Clin Exp Med 7: 2453-2462, 2014.

37. David JM and Rajasekaran AK: Dishonorable discharge: The oncogenic roles of cleaved E-cadherin fragments. Cancer Res 72: 2917-2923, 2012

38. Xia W, Ma X, Li X, Dong H, Yi J, Zeng W and Yang Z: miR-153 inhibits epithelial-to-mesenchymal transition in hepatocellular carcinoma by targeting Snail. Oncol Rep 34: 655-662, 2015.

39. Liao ZJ, Guo YH, Zhao Z, Yao JT, Xu R and Nan KJ: Gemcitabine inhibits the micrometastasis of non-small cell lung cancer by targeting the EpCAM-positive circulating tumor cells via the HGF/cMET pathway. Int J Oncol 45: 651-658, 2014.

40. Quan MF, Xiao LH, Liu ZH, Guo H, Ren KQ, Liu F, Cao JG and Deng XY: 8-bromo-7-methoxychrysin inhibits properties of liver cancer stem cells via downregulation of $\beta$-catenin. World J Gastroenterol 19: 7680-7695, 2013.

41. Hu Z and Zhao W: Novel insights into the molecular mechanisms of $\alpha$-fetoprotein expression and malignant phenotypes of hepatocellular carcinoma. Cell Mol Immunol 9: 7-8, 2012.

42. Kim HA, Nam K, Lee M and Kim SW: Hypoxia/hepatoma dual specific suicide gene expression plasmid delivery using bio-reducible polymer for hepatocellular carcinoma therapy. J Control Release 171: 1-10, 2013.

43. Garcia-Martinez R, Caraceni P, Bernardi M, Gines P, Arroyo V and Jalan R: Albumin: Pathophysiologic basis of its role in the treatment of cirrhosis and its complications. Hepatology 58 1836-1846, 2013

44. You J, Raghunathan VK, Son KJ, Patel D, Haque A, Murphy CJ and Revzin A: Impact of nanotopography, heparin hydrogel microstructures, and encapsulated fibroblasts on phenotype of primary hepatocytes. ACS Appl Mater Interfaces 7: 12299-12308, 2015.

45. Ohguchi S, Nakatsukasa H, Higashi T, Ashida K, Nouso K, Ishizaki M, Hino N, Kobayashi Y, Uematsu S and Tsuji T: Expression of alpha-fetoprotein and albumin genes in human hepatocellular carcinomas: Limitations in the application of the genes for targeting human hepatocellular carcinoma in gene therapy. Hepatology 27: 599-607, 1998.

46. Toro A, Ardiri A, Mannino M, Arcerito MC, Mannino G, Palermo F, Bertino G and Di Carlo I: Effect of pre- and posttreatment $\alpha$-fetoprotein levels and tumor size on survival of patients with hepatocellular carcinoma treated by resection, transarterial chemoembolization or radiofrequency ablation: A retrospective study. BMC Surg 14: 40, 2014.

47. Nojiri S and Joh T: Albumin suppresses human hepatocellular carcinoma proliferation and the cell cycle. Int J Mol Sci 15: 5163-5174, 2014

48. Vernon AE and LaBonne C: Tumor metastasis: A new twist on epithelial-mesenchymal transitions. Curr Biol 14: R719-R721, 2004.

49. Valastyan S and Weinberg RA: Tumor metastasis: Molecular insights and evolving paradigms. Cell 147: 275-292, 2011.

50. Yin P, Wang Y, Qiu Y, Hou L, Liu X, Qin J, Duan Y, Liu P, Qiu M and Li Q: Bufalin-loaded mPEG-PLGA-PLL-cRGD nanoparticles: Preparation, cellular uptake, tissue distribution, and anticancer activity. Int J Nanomed 7: 3961-3969, 2012. 